\title{
The Effects of Guided Inquiry Learning with the Assistance of Concept Maps on Students' Scientific Literacy
}

\author{
I Putu Artayasa ${ }^{1 *}$, Muhlis ${ }^{1}$, I Wayan Merta ${ }^{1}$, Gito Hadiprayitno ${ }^{1}$ \\ ${ }^{1}$ Biology Education Study Program, University of Mataram, Mataram, Indonesia.
}

DOI: $10.29303 /$ jppipa.v7i2.692

\section{Article Info}

Received : March 13th, 2021

Revised : April 16th, 2021

Accepted: April 19th, 2021

\begin{abstract}
The purpose of this study is to examine the effect of the application of the guided inquiry learning model assisted by concept maps on the scientific literacy of junior high school students in the city of Mataram. The research was conducted through a pretestposttest design with a non-randomized control group. The sampling technique was purposive sampling. The sample of 90 students was divided into three classes, where the first-class applied guided inquiry learning assisted by concept maps, the second class applied inquiry learning without the help of concept maps, and the third class applied conventional learning. All classes were given a pretest and posttest scientific literacy. Data in the form of pretest and posttest scores were analyzed by Analysis of Variance (ANOVA) and continued with the Least Significance Difference (LSD) test at 5\% alpha. The results showed that the mean score of students' scientific literacy in the class that applied the guided inquiry learning model assisted by concept maps was significantly higher than the mean score of the conventional class. The conclusion is that there is an effect of the implementation of the inquiry learning model assisted by the concept map method on students' scientific literacy.
\end{abstract}

Keywords: guided inquiry; scientific literacy; concept maps; junior high school science lessons.

Citation: Artayasa, I., Muhlis, M., Merta, I., \& Hadiprayitno, G. (2021). The Effects of Guided Inquiry Learning with the Assistance of Concept Maps on Students' Scientific Literacy. Jurnal Penelitian Pendidikan IPA, 7(2), $262-268$. doi:https://doi.org/10.29303/ippipa.v7i2.692

\section{Introduction}

Scientific literacy is the ability to understand science and use it to solve problems in everyday life. According to the Organization for Economic Cooperation and Development (OECD) (2013), scientific literacy is scientific knowledge and the use of that knowledge to identify questions, acquire new knowledge, explain scientific phenomena, and draw evidence-based conclusions about problems related to science. Scientific literacy is very important for students because scientific literacy skills play a role in determining the success of citizens of a nation (Nofiana \& Julianto, 2017). Ileriturk and Kincal (2018) state that a country's scientific literacy rating based on the results of the PISA evaluation is positively correlated to the productivity of its citizens. Productivity is measured based on the number of innovations, such as patents produced.

The results of the PISA evaluation on students aged 15 years showed that the scientific literacy of Indonesian students was still low. Indonesian students are always ranked in the bottom 10 of the $60-70$ countries that participate in the PISA evaluation (Kemendikbud, 2013; Nofiana \& Julianto, 2017; OECD, 2016; OECD 2019). According to Firman (2007) as cited by Dian et al. (2016), one of the causes of the low scientific literacy skills of Indonesian students is the application of textual and less contextual learning. Furthermore, Fuadi et al. (2020) stated that the factors 
that cause the low level of students' scientific literacy are an improper selection of teaching materials, misconceptions, learning that is not contextual, and students' reading ability. Naturasari et al. (2016) also stated that the selection of a learning model that does not provide students to apply science process skills such as conducting investigations is also the cause of the low scientific literacy of Indonesian students.

The results of the PISA evaluation are important information for consideration in choosing an effective learning model to improve students' scientific literacy. Current science learning should not only emphasize cognitive development at the level of memorization and understanding which includes low-level thinking skills but also more directed at developing scientific literacy through increasing students' ability to use knowledge to solve everyday problems. This is in accordance with the content of the PISA evaluation which emphasizes measuring the ability of students to use scientific knowledge, identify questions, and draw conclusions based on evidence in order to understand and make decisions regarding nature and changes made to nature (OECD, 2013).

The solution to the problem of students' low scientific literacy is if learning is packaged in an attractive learning model that is able to encourage students to build their own concepts through learning with a scientific, contextual approach, involving students' daily aspects, and utilizing the surrounding environment and local wisdom, so as to increase student activity (Dian et al., 2016). A similar statement is said that increasing scientific literacy requires mastery of science process skills (Feyzioglu et al., 2012), therefore these process skills are a major component of the application of the scientific approach in the 2013 curriculum. Several research results show that guided inquiry learning is the most effective learning model for improving process skills and scientific literacy of junior high school students (Fatmawati \& Utari, 2015; Hardianti \& Kuswanto, 2017).

The application of guided inquiry learning begins with activities to formulate problems, and then formulate hypotheses and create experimental designs (Llewellyn, 2013). The preparation of experimental designs is difficult for students to implement in learning activities (Artayasa et al., 2017; Subali, 2009) because conventional learning that has been applied so far is not optimal in facilitating the development of student skills in experimental activities (Anggraini, 2012). In other words, the implementation of guided inquiry learning can run well if students have good science process skills too, so it is necessary to find a practical inquiry learning model that can help students improve their science process skills.
Guided inquiry learning when applied to students who are inexperienced in conducting experiments can cause students to become frustrated in learning (Bunterm et al., 2014; Hodson, 2009). They do not know what to do. Thus, this problem needs to be addressed, for example providing assistance by integrating other methods into the stages of guided inquiry learning, especially at the stage where students formulate hypotheses and experimental designs. The integration of other methods is likened to a ladder that can help students go to a higher place. This other method serves to focus students' minds to relate topics or activities to one another, leading to the development of hypotheses and experimental activities. The method of focusing the mind by linking topics or concepts to one another is called the concept map method (Tapantoko, 2011; Widyastuti, 2010).

Increasing the scientific literacy of junior high school students in the City of Mataram is an urgent matter to be done. Lestari's research (2019) on 248 students spread across five junior high schools in Mataram City showed that nearly $50 \%$ of students have low and very low categories of scientific literacy scores, and only $5 \%$ have high scientific literacy scores. The mean score of the junior high school students' scientific literacy was 53 which was in the low category. Analysis of Student Worksheets (SW) applied by teachers at Mataram City Junior High School shows that the SW trains students more to explain phenomena scientifically and has less effort to train science process skills, such as designing scientific investigations, interpreting data, and proving scientific investigations. Research on science educators at the Mataram City Junior High School also shows that $50 \%$ of teachers have a low category of scientific literacy scores (Jamalludin et al., 2019). Therefore, the aim of this research is to test whether there is an effect of the application of guided inquiry learning assisted by concept maps on the scientific literacy of junior high school students in Mataram so that their scientific literacy does not continue to lag behind students in other cities.

\section{Method}

The independent variable of the research is the application of a different learning model, namely the inquiry learning model and conventional learning, while the dependent variable is students' scientific literacy. The study was conducted with a pretestposttest design with a non-randomized control group. The research took place in the even semester of the 2020/2021 school year. The description of the research design is presented in Table 1. Based on the research 
design, there were three learning models applied, namely: the guided inquiry learning model with the application of the concept map method (EX1, 2), the inquiry learning model without the application of the concept map (EX1), and the conventional learning model (CX0).

Table 1. Research Design

\begin{tabular}{llll}
\hline Groups & Pre-test & Treatment & Post-test \\
\hline E & $\mathrm{O}_{1}$ & $\mathrm{X}_{1,2}$ & $\mathrm{O}_{2}$ \\
E & $\mathrm{O}_{3}$ & $\mathrm{X}_{1}$ & $\mathrm{O}_{4}$ \\
C & $\mathrm{O}_{5}$ & $\mathrm{X}_{0}$ & $\mathrm{O}_{6}$ \\
\hline
\end{tabular}

Where;

$\mathrm{X}_{1}$ : The application of guided inquiry learning

$\mathrm{X}_{2}$ : Application of the concept map method

$\mathrm{X}_{0}$ : Application of conventional learning

$\mathrm{E}:$ Inquiry Class

C : Conventional Class

(Adapted from Ali \& Asrori, 2014)

The research was conducted on junior high school students in the city of Mataram. Sampling was performed by using the purposive sampling technique because the sampling was carried out based on a specific objective. The objective is to select a sample of two schools based on consideration of school performance on the 2019 national exam. Based on the list of the average national exam scores from the Mataram City Junior High Schools, then one school representative who occupies the upper group and one representative from the lower group was selected. Students from each school were then divided into three classes, namely, the first class applies the guided inquiry learning model assisted by concept maps, the second class implements inquiry learning without the help of concept maps, and the third class applies conventional learning.

The research instrument consisted of a scientific literacy test. The form of the test used was multiplechoice (objective). The scientific literacy test indicators are presented in Table 2 .

Table 2. Indicators of Scientific Literacy Test

\begin{tabular}{lll}
\hline No & Indicators of Scientific Literacy* & Test Form \\
\hline 1 & Explain phenomena scientifically & Objective \\
2 & $\begin{array}{l}\text { Evaluating and designing scientific } \\
\text { investigations } \\
3\end{array}$ & $\begin{array}{l}\text { Objective } \\
\text { scientifically }\end{array}$ \\
\hline
\end{tabular}

* Indicators of scientific literacy according to PISA (OECD, 2016).

All classes were given a scientific literacy pretest and posttest. Data analysis was carried out in stages. First stage, a sample equivalence test was conducted based on pretest data. Second, the treatment effect test on scientific literacy was carried out based on post-test data. Data in the form of pretest and posttest scores were analyzed by analysis of variance (ANOVA) and continued with the least significant difference test (LSD) to determine whether the three classes had a mean scientific literacy score that was significantly different or not. If the inquiry class that applies the concept map method has a higher test score, it can be concluded that there is an effect of the application of the learning model on students' scientific literacy. Before the Anova and LSD tests were performed, the scientific literacy test data were confirmed to be normally distributed and have homogeneous variances. The data normality test was carried out by the Kolmogorov-Smirnov test, while the data homogeneity test was carried out by Levene's Test of Equality of Error Variances (Prayitno, 2012). All tests were carried out with a statistical software package, namely SPSS for Windows Version 25.

The learning process in each school (three classes) was conducted by a science teacher. The teacher applied three learning models in different classes, namely the guided inquiry learning model assisted by concept maps, the guided inquiry model without concept maps, and the conventional learning model. Communication in learning was conducted online through google classroom (GC). Through GC, the teacher delivered teaching materials in the form of Student Worksheets (SW) developed by the research team, namely teaching materials based on guided inquiry with concept map preparation (Figure 1), guided inquiry teaching materials without drafting concept maps, and conventional teaching materials.

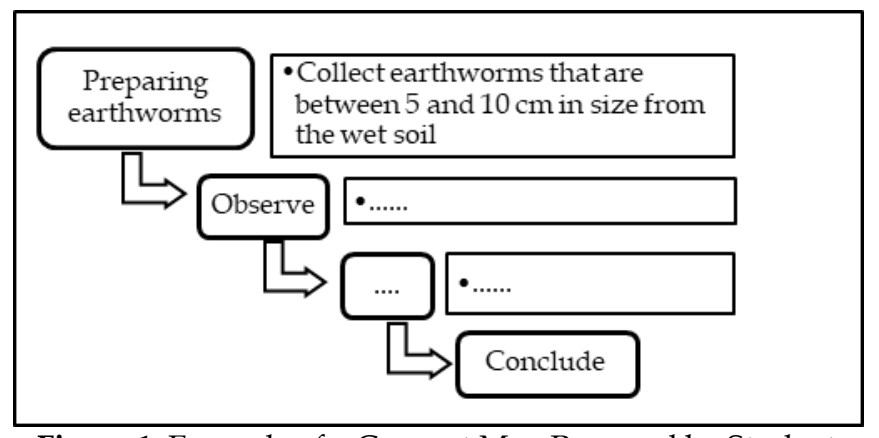

Figure 1. Example of a Concept Map Prepared by Students

There were two kinds of concept maps prepared by students, the first concept map asks students to make or complete a concept map before the students conduct the experiment, while the second concept map is prepared after the students have completed the experiment. The first concept map aims to direct students to carry out the investigative steps appropriately, while the second concept map aims to 
reinforce the learning that has been done. The topic that students learn is the Movement System of Living Things.

\section{Result and Discussion}

\section{Sample Equivalence Test Results}

The equivalence test was performed to determine whether students from all of the research samples had the same initial ability or not. The equality of students' initial abilities is the basis for ascertaining whether differences in research results are due to differences in treatment, not because of differences in initial abilities. This test was done by giving a pretest to all students who are the research sample. The pretest questions consist of twenty objective questions with the content that matches the content that the students will study during the research. The equivalence test was carried out by the Anova test at alpha 0.05 and before the Anova test was conducted, the normality test and the homogeneity test were first performed. The test results indicate that the pretest score is normally distributed ( $p$ $>0.05$ ) and has a homogeneous variance with a Levene test value of 0.148 and a significance value of 0.863 which means it has $p>0.05$, so that the pretest score meets the requirements tested by Anova. The results of the equivalence test with Anova are presented in Tables 3 and 4 .

Table 3. Mean Pretest Score

\begin{tabular}{llllc}
\hline Class & $\begin{array}{l}\text { Total } \\
\text { students }\end{array}$ & $\begin{array}{l}\text { Mean } \\
\text { Score }\end{array}$ & $\begin{array}{l}\text { Standart } \\
\text { Error (SE) }\end{array}$ & $\begin{array}{l}\text { Equality } \\
\text { Notation }\end{array}$ \\
\hline A & 29 & 55.17 & 3.250 & $\mathrm{a}$ \\
B & 30 & 61.33 & 3.041 & $\mathrm{a}$ \\
B & 32 & 53.75 & 3.471 & $\mathrm{a}$ \\
\hline
\end{tabular}

Where;

$\mathrm{A}=$ Inquiry class with concept maps

$\mathrm{B}=$ Inquiry class without a concept map

$\mathrm{C}=$ Conventional class

Table 4. Anova Test Results for Pretest Data

\begin{tabular}{llllll}
\hline & $\begin{array}{l}\text { Sum of } \\
\text { Squares }\end{array}$ & df & $\begin{array}{l}\text { Mean } \\
\text { Square }\end{array}$ & F & $\begin{array}{l}\text { Sig. } \\
(p)\end{array}$ \\
\hline Between & 990.184 & 2 & 495.092 & 1.525 & .223 \\
$\begin{array}{l}\text { Groups } \\
\text { Within Groups }\end{array}$ & 28570.805 & 88 & 324.668 & & \\
Total & 29560.989 & 90 & & & \\
\hline
\end{tabular}

Based on Table 3, the mean pretest score for the inquiry class that applies the concept map is 55.17, the class that applies inquiry learning without making a concept map is 61.33, while the mean score for the conventional class is 53.75. The three classes have a mean with the same notation, namely a, which means that the three classes have a mean score that is not significantly different at alpha 0.05 . This was evidenced by the results of the Anova test (Table 4) that students from the three classes had equal initial abilities as indicated by the value of $\mathrm{F}=1.53$, and significance or $p$ $=0.22$ or indicating $p>0.05$.

\section{Treatment Effect Test Results}

Testing the effect of treatment on students' scientific literacy abilities was performed through the application of twenty scientific literacy tests. Before being applied to students, these questions have been tested by validators or experts (lecturers of Biology Education, FKIP, Mataram University) and science teachers of SMP 3 and 7 Mataram. The application of the scientific literacy test was conducted after the students have completed the lesson on the Movement System of Living Things. The mean score of students' scientific literacy is presented in Table 5.

Table 5. Mean Scientific Literacy Score

\begin{tabular}{lllll}
\hline Class & $\begin{array}{l}\text { Total } \\
\text { students }\end{array}$ & $\begin{array}{l}\text { Mean } \\
\text { Score }\end{array}$ & $\begin{array}{l}\text { Standard } \\
\text { Error (SE) }\end{array}$ & $\begin{array}{l}\text { LSD } \\
\text { notation }\end{array}$ \\
\hline A & 29 & 78.62 & 2.648 & a \\
B & 30 & 73.83 & 3.885 & a \\
C & 32 & 60.16 & 4.292 & b \\
\hline
\end{tabular}

Where;

$\mathrm{A}=$ Inquiry class with concept maps

$\mathrm{B}=$ Inquiry class without a concept map

$\mathrm{C}=$ Conventional class

Based on Table 5, the mean score of scientific literacy in inquiry class students who applies concept map preparation is 78.62 which is higher than the mean score of the inquiry class without applying concept maps is 73.83 and the average score for conventional class is 60.16 . The normality and homogeneity test of the scientific literacy score shows that the scores are normally distributed and have a homogeneous variance which is indicated by a significant value or $p$ greater than 0.05, as shown in Tables 6 and 7.

Table 6. Normality Test Results

\begin{tabular}{lllllll}
\hline & \multicolumn{3}{l}{ Kolmogorov-Smirnov } & \multicolumn{3}{l}{ Shapiro-Wilk } \\
\cline { 2 - 7 } Class & Statistic & df & Sig. $(p)$ & Statistic & df & Sig. $(p)$ \\
\hline A & .118 & 29 & .200 & .934 & 29 & .071 \\
B & .225 & 30 & .000 & .927 & 30 & .040 \\
C & .136 & 32 & .138 & .943 & 32 & .093 \\
\hline
\end{tabular}

Table 7. Homogeneity Test Results

\begin{tabular}{lllll}
\hline & Levene Statistic & df1 & df2 & Sig. $(p)$ \\
\hline $\begin{array}{l}\text { Based on } \\
\text { Mean }\end{array}$ & 2.647 & 2 & 88 & .077 \\
\hline
\end{tabular}

The results of hypothesis testing related to the scientific literacy variable were obtained based on the Anova test results. Based on the ANOVA test, it was 
found that the mean score between the three classes was significantly different with the value of $F=6.72$ and sig $(p)=0.02$ or less than $p=0.05$, as shown in Table 8 .

Table 8. Results of the Anova Test for scientific literacy

\begin{tabular}{lllllll}
\hline \multicolumn{2}{c}{$\begin{array}{l}\text { Sum of } \\
\text { Squares }\end{array}$} & df & $\begin{array}{l}\text { Mean } \\
\text { Square }\end{array}$ & F & $\begin{array}{l}\text { Sig. } \\
(p)\end{array}$ \\
\hline $\begin{array}{l}\text { Scientific } \\
\text { literacy }\end{array}$ & Between & 5669.314 & 2 & 2834.657 & 6.723 & .002 \\
& $\begin{array}{l}\text { Groups } \\
\text { Within }\end{array}$ & 37103.213 & 88 & 421.627 & & \\
& $\begin{array}{l}\text { Groups } \\
\text { Total }\end{array}$ & 42772.527 & 90 & & & \\
\hline
\end{tabular}

Based on the LSD test (Table 9), the class of inquiry that applied and did not apply the concept map had a mean score that was not significantly different $(p$ $=0.373$ ), but both were significantly different from the conventional class $(p=0.001$ and $p=0.01$ or both has $p$ $<0.05)$.

Table 9. Scientific literacy LSD Test Results

\begin{tabular}{|c|c|c|c|c|c|}
\hline $\begin{array}{l}\text { Dependent } \\
\text { Variable }\end{array}$ & $\begin{array}{l}\text { (I) } \\
\text { Class }\end{array}$ & $\begin{array}{l}\text { (J) } \\
\text { Class }\end{array}$ & $\begin{array}{l}\text { Mean } \\
\text { Difference } \\
\text { (I-J) }\end{array}$ & $\begin{array}{l}\text { Std. } \\
\text { Error }\end{array}$ & Sig. $(p)$ \\
\hline Scientific & A & B & 4.787 & 5.347 & .373 \\
\hline \multirow[t]{5}{*}{ Literacy } & & C & $18.464^{*}$ & 5.264 & .001 \\
\hline & B & A & -4.787 & 5.347 & .373 \\
\hline & & C & $13.677^{*}$ & 5.218 & .010 \\
\hline & $\mathrm{C}$ & $\bar{A}$ & $-18.464^{*}$ & 5.264 & .001 \\
\hline & & B & $-13.677^{*}$ & 5.218 & .010 \\
\hline
\end{tabular}

Based on the results of this study, the inquiry class has a better ability to answer scientific literacy questions which include activities to explain phenomena scientifically, design experiments, and interpret and prove data scientifically. This is possible because, in this study, the inquiry class was given an SW which contained an inquiry activity guide. The guide contains experimental activities that students must do independently or in groups. Giving students the opportunity to design their own experiments will encourage students to actively seek information about scientific phenomena related to their experiments and increase their interest in analyzing and interpreting experimental data (Artayasa et al. (2017). This is in accordance with the opinion of Fatmawati and Utari (2015) that through the stages of investigation activities, students can state facts and explain scientific phenomena, and students are given the opportunity to evaluate and design scientific research and are trained to be able to interpret data and scientific evidencebased on experiments that have been carried out. Likewise, it is said that students who apply guided inquiry learning have a positive attitude towards learning (Bilgin, 2009), and have learning motivation that increases significantly compared to the application of conventional learning (Lintuan et al., 2005).

In this study, there were two kinds of SW that were made, namely SW which was accompanied by activities to make concept maps, and SW without asking students to make concept maps. The results of this study indicate that the mean score of the inquiry class that applies the concept map is higher than that of the inquiry class that does not apply the concept map, although based on the LSD test the difference is not significant. The task of compiling a concept map on the SW encourages students to analyze the relationship between one concept and another. The benefit of drafting a concept map according to Aprinawati (2018) is that it makes it easier for the brain to understand information because the way concept maps work is similar to how neural connections in the brain work. Concept map development also makes it easier for someone to develop ideas because they can start with the main idea and then use the connections in the brain to break it down into more detailed ideas (Widyastuti, 2010). According to Tapantoko (2011), the application of concept maps can improve students' memorization and motivation to learn and cause students to be more creative.

\section{Conclusion}

The conclusion of this study is that there is a significant effect of the application of guided inquiry learning assisted by concept maps on students' scientific literacy. Students who apply inquiry learning accompanied by concept map-making have higher scientific literacy than students who apply conventional learning. Based on these conclusions, the suggestion that can be given is if the educator tries to apply guided inquiry learning accompanied by the assignment of making concept maps.

\section{Acknowledgments}

Thanks to the University of Mataram for funding this research through the DIPA BLU University of Mataram funding source for the 2020 fiscal year with an agreement letter number 2628 / UN18.L1 / PP / 2020. Thanks, are also conveyed to partner teachers from SMPN 3 Mataram and SMPN 7 Mataram: Fitran Sari, Miskah, and Rohaini for their willingness to become teachers and facilitate research activities, as well as to Sri Sukma Wati and Baiq Fitri Raudatul Hikmah who were involved in developing SW. 


\section{References}

Ali, M., \& Asrori, M. (2014). Metode dan Aplikasi Riset Pendidikan. Jakarta, Indonesia: Bumi Aksara. [Indonesian]

Anggraini, S. (2012). Profil Kemampuan Melakukan Inkuiri Melalui Kegiatan Miniriset Calon Guru Biologi dalam Perkuliahan Fisiologi Tumbuhan. Proceeding Seminar Nasional Cakrawala Pembelajaran Berkualitas di Indonesia. Direktorat Pendidik dan Tenaga Kependidikan Direktorat Jenderal Pendidikan Tinggi Kementerian Pendidikan dan Kebudayaan, Jakarta. [Indonesian]

Aprinawati, I. (2018). Penggunaan Model Peta Pikiran (Maind Mapping) untuk Meningkatkan Pemahaman Membaca Wacana Siswa Sekolah Dasar. Jurnal Basicedu. 2(1), 140-147. doi: https://doi.org/10.31004/basicedu.v2i1.132 [Indonesian]

Artayasa, I P., Susilo, H., Lestari, U., \& Indriwati, S. E. (2017). The Effectiveness of the Three Levels of Inquiry in Improving Teacher Training Students' Science Process Skills. Journal of Baltic Science Education, 16(6), 908-918.

Bilgin, I. (2009). The effects of guided inquiry instruction incorporating a cooperative learning approach on university students' achievement of acid and bases concepts and attitude toward guided inquiry instruction. Scientific Research and Essay, 4(10): 1038-1046.

Bunterm, T., Lee, K., Kong, J. N. L., Srikoon, S., Vangpoomyai, P., Rattanavongsa, J., \& Rachahoon, G. (2014). Do Different Levels of Inquiry Lead to Different Learning Outcomes? A Comparison between Guided and Structured Inquiry. International Journal of Science Education, 36(12), 1937-1959. doi:http://dx.doi.org/10.1080/09500693.2014.88 $\underline{6347}$

Dian, D.D., Lisdiana, \& Sukaesih, S. (2016). Pengaruh Pembelajaran Berbasis Proyek Berbantuan Modul Daur Ulang Limbah Pada Literasi Sains. Journal of Biology Education, 5 (3), 302-309. doi: https://doi.org/10.15294/jbe.v5i3.14864 [Indonesian]

Fatmawati, I. N., \& Utari, S. (2015). Penerapan Levels of Inquiry untuk Meningkatkan Literasi Sains Siswa SMP Tema Limbah dan Upaya Penanggulangannya. Edusains, 7 (2): 151-159. Retrived from https://media.neliti.com/media/publications/5 9942-ID-penerapan-levels-of-inquiry-untukmening.pdf [Indonesian]

Feyzioglu, B., Demirdag, B., Akyilidz, M., \& Altun, E.
(2012). Developing a Science Process Skills Test for Secondary Student: Validity and Reliability Study. Education Sciences: Theory \& Practice, 12 (3), 1899-1906.

Fuadi, H., Robbia, A. Z., Jamaluddin, \& Jufri, A. W. (2020). Analisis Faktor Penyebab Rendahnya Kemampuan Literasi Sains Peserta Didik, Jurnal Ilmiah Profesi Pendidikan, 5 (2), 108-116. doi: https://doi.org/10.29303/iipp.v5i2.122109 [Indonesian]

Hardianti, T. \& Kuswanto, H. (2017). Difference Among Levels of Inquiry: Process Skills Improvement at Senior High School in Indonesia. International Journal of Instruction, 10(2), 119-130.

Hodson, D.(2009). Teaching and Learning about Science: Language, Theories, Methods, History, Traditions, and Values. Rotterdam: Sense Publishers.

Ileriturk, D., \& Kincal, R. Y. (2018). Analysis of Pisa Participant Countries' Success Rankings in Terms of Their Patent Productivities. International Journal of Instruction, 11 (4): 191-206. https://doi.org/10.12973/iji.2018.11413a

Jamaluddin, Jufri A. W., Ramdhani, A., \& Azizah A. (2019). Profil Literasi Sains dan Keterampilan Berpikir Kritis Pendidik IPA SMP. Jurnal Penelitian Pendidikan IPA, 5(1), 120-130. doi: https://doi.org/10.29303/jppipa.v5i1.185. [Indonesian]

Kemendikbud. (2013). Implementasi Kurikulum 2013. Jakarta, Indonesia: Badan Pengembangan Sumber Daya Manusia Pendidikan dan Kebudayaan dan Penjaminan Mutu Pendidikan. [Indonesian]

Lestari, A. (2019). Analisis Lembar Kerja Peserta Didik (LKPD) dan Kemampuan Literasi Sains Pada Mata Pelajaran Ilmu Pengetahuan Alam (IPA) Biologi Kelas VIII SMPN Di Kecamatan Mataram. (Unpublished Skripsi). FKIP Universitas Mataram, Mataram. [Indonesian]

Lintuan, H., Chin, C-C., Tsai, C-C \& Cheng, S-F. (2005). Investigating the effectiveness of inquiry instruction on the motivation of different learning styles students. International Journal of Mathematics Education, 3, 541-566. Doi: https://doi.org/10.1007/s10763-004-6827-8

Llewellyn, D. (2013). Teaching High School Science Through Inquiry and Argumentation. (Second edition). California, USA: Corwin, A Sage Company.

Naturasari, H., Roshayanti F., Nurwahyunani, A., (2016). Profil Kualitas Literasi Sains Siswa SMP Se-Kabupaten Pati. Bioma, 5(2). Retrieved from; http://journal.upgris.ac.id/index.php/bioma/a rticle/download/2503/1895. [Indonesian]

Nofiana, M., \& Julianto, T.( 2017). Profil Kemampuan 
Literasi Sains Siswa SMP Di Kota Purwokerto Ditinjau dari Aspek Konten, Proses, dan Konteks Sains. Jurnal Sains Sosial dan Humaniora, 1(2), 7784. doi: 10.30595/jssh.v1i2.1682 [Indonesian]

OECD (2013), PISA 2012 Assessment and Analytical Framework: Mathematics, Reading, Science, Problem Solving and Financial Literacy, OECD Publishing. http://dx.doi.org/10.1787/9789264190511-en

OECD (2019). PISA 2018 Results. Retrieved from https://www.oecd.org/pisa/Combined_Executi ve_Summaries_PISA_2018.pdf.

OECD. (2016). PISA 2015 PISA Result in Focus. Retrieved from https://www.oecd.org.pdf.

Prayitno, D. (2012). Belajar Cepat Olah Data Statistik dengan SPSS. Yogyakarta, Indonesia: Penerbit ANDI. [Indonesian]

Subali, B. (2009). Pengembangan Tes Pengukuran Keterampilan Proses sains Pola Divergen Mata Pelajaran Biologi SMA. Prosiding Seminar Nasional Pendidikan, Lingkungan dan Pembelajarannya. Jurdik Biologi FMIPA Universitas Negeri Yogyakarta, Yogyakarta. [Indonesian]

Tapantoko, A. A. (2011). Penggunaan Metode Maind Map (Peta Pikiran) untuk Meningkatkan Motivasi Belajar Siswa dalam Pembelajaran Matematika Siswa Kelas VIII SMP Negeri 4 Depok. (Unpublished Skripsi). Universitas Negeri Yogyakarta, Yogyakarta. [Indonesian]

Widyastuti, S. (2010). Menggunakan Metode Peta Pikiran (Maind mapping) dalam Menulis. Paper presented at Seminar Metode Belajar yang Efektif, 25 September 2010, Retrieved from: https://docplayer.info/30813785-Menggunakanmetode-peta-pikiran-mind-mapping-dalammenulis.html. [Indonesian] 